\title{
DIAGNOSIS DAN PENATALAKSANAAN ANGIOEDEMA DI BIDANG THT-KL
}

\author{
I Gusti Ayu Oka Sari Utari*, Putu Sudiasa**, R Yully Prapyatiningsih*** \\ Bagian Imu Kesehatan THT-KL RSUD Bangli Bali
}

\begin{abstract}
ABSTRAK
Angioedema adalah edema yang melibatkan lapisan yang lebih dalam dari kulit yaitu dermis, jaringan subkutan, mukosa dan submukosa karena terjadinya peningkatan permeabilitas kapiler akibat mediator inflamasi. Angioedema pertama kali disebarluaskan oleh Heinrich Quincke pada tahun 1882 sehingga angioedema sering juga disebut dengan Quincke edema. Pada angioedema, edema yang timbul adalah non-pitting, berbatas tegas, pucat dan tidak gatal namun angioedema dapat juga timbul bersamaan dengan urtikaria sehingga bisa disertai gatal-gatal dan kemerahan. Angioedema dapat terjadi pada daerah wajah terutama di daerah bibir dan mata, telinga, saluran pernafasan, saluran pencernaan, kardiovaskuler, tangan, kaki dan alat kelamin. Apabila terjadi pada lidah dan saluran pernafasan bagian atas serta berlangsung dengan cepat, dapat mengancam nyawa karena terjadinya obstruksi jalan nafas.Gejala angioedema terkadang sangat mirip dengan beberapa kelainan yang lain. Pengetahuan mengenai cara mendiagnosis angioedema sangat penting sehingga dapat dilakukan penatalaksanaan yang tepat. Dengan demikian penulis tertarik untuk membuat suatu tinjauan pustaka mengenai diagnosis dan penatalaksanaan angioedema khususnya di bidang THT.
\end{abstract}

Kata Kunci : Angioedema, Quincke edema, THT.

\section{PENDAHULUAN}

\section{Epidemiologi}

Angioedema dapat terjadi pada semua usia tetapi paling sering terjadi pada usia dewasa muda. ${ }^{6}$ Sekitar 10 - 20 $\%$ penduduk di seluruh dunia akan mengalami angioedema dalam masa kehidupan mereka, kejadiannya sama antara wanita dan laki-laki, sedangkan di Amerika angka kejadiannya sekitar 15 $25 \%$ dari seluruh penduduk. ${ }^{7}$ Angioedema dapat muncul dengan ataupun tanpa urtikaria. Sekitar 50\% pasien mengalami angioedema bersamaan dengan urtikaria, $10 \%$ pasien mengalami angioedema tanpa disertai urtikaria dan $40 \%$ pasien mengalami urtikaria tanpa adanya angioedema. ${ }^{2,6}$

\section{Angiotensin-converting enzyme} inhibitor atau ACE inhibitor adalah obat yang paling sering menyebabkan angioedema. Antara 0,1\% - 0,68\% pasien yang mengkonsumsi obat ini dapat mengalami angioedema. ${ }^{8,9}$ Sebanyak $47 \%-72 \%$ kasus terjadi dalam minggu pertama setelah mulai pengobatan tetapi dapat juga terjadi setiap saat selama pengobatan. ${ }^{9} A C E$ inhibitor adalah obat antihipertensi seperti kaptopril, enalapril, benzapril, cilazapril, lisinopril, perindopril dan ramipril. Sedangkan Nonsteroid anti-inflammatory drug atau NSID dapat menyebabkan angioedema pada $0,1 \%$ - $0,3 \%$ pasien yang mengkonsumsi obat ini. ${ }^{10}$

Angioedema herediter adalah kelainan yang langka. Angka kejadiannya sekitar $1 \%$ dari seluruh kasus angioedema dan prevalensinya $\begin{array}{llll}\text { sekitar } 1 & \text { kasus per } 50.000\end{array}$ 
penduduk. $^{11,12}$ Angioedema herediter merupakan penyakit akibat kelainan autosomal dominan yang dibagi menjadi angioedema herediter tipe I yang terjadi pada $80 \%-85 \%$ pasien dan angioedema herediter tipe II yang terjadi pada $15 \%$ - 20\% pasien. ${ }^{11-13}$ Pada penelitian yang dilakukan oleh Bork $\mathrm{K}$ dkk pada tahun 2006 seperti dikutip oleh Coughlin A dkk pada tahun $2012^{14}$ didapatkan kejadian angioedema herediter pada ekstremitas 47 $\%$, saluran pencernaan $33 \%$ dan di daerah rongga mulut, faring serta laring sebanyak $6 \%$.

\section{Anatomi}

Angioedema di daerah THT dapat mengenai bibir, lidah, palatum, faring maupun laring. ${ }^{1}$ Bibir tersusun dari otot rangka dan jaringan ikat. Permukaan luar bibir dilapisi kulit mengandung folikel rambut, kelenjar keringat serta kelenjar subasea. Permukaan dalam bibir adalah membran mukosa. Sedangkan lidah terdiri dari kumpulan otot rangka. Lidah dilekatkan pada dasar mulut oleh frenulum lingua. Otot extrinsik lidah berawal pada tulang dan jaringan diluar lidah berfungsi dalam pengerakan lidah secara keseluruhan. Otot intrinsik lidah memiliki serabut yang menghadap keberbagai arah untuk membentuk sudut satu sama lain. ${ }^{15,16}$ Palatum adalah bagian langit-langit mulut. Palatum dibagi menjadi 3 yaitu palatum mole, palatum durum, raphe palati. Palatum mole adalah langit-langit mulut yang berada di bawah dan sebelah uvula dan letaknya paling belakang. Palatum durum adalah langitlangit mulut yang berada paling atas, di sebelah belakang gigi seri dan gigi taring. Raphe palati adalah langit-langit mulut yang tampak menonjol dan memanjang mulai dari depan hingga belakang palatum. ${ }^{16}$

Faring adalah suatu struktur fibromuskuler yang memanjang dari dasar tengkorak sampai persambungannya dengan esofagus pada ketinggian tulang rawan krikoid yang berbentuk seperti corong dengan bagian atas yang besar dan bagian bawah yang sempit. Faring merupakan ruang utama traktus respiratorius dan traktus digestivus. Panjang dinding posterior faring pada orang dewasa $\pm 14 \mathrm{~cm}$ dan bagian ini merupakan bagian dinding faring yang terpanjang. Dinding faring dibentuk oleh selaput lendir, fasiafaringobasiler, pembungkus otot dan sebagian fasia bukofaringeal. $^{15,16}$ Berdasarkan letaknya maka faring dapat dibagi menjadi nasofaring, orofaring dan laringofaring atau disebut juga dengan hipofaring. Nasofaring merupakan bagian tertinggi dari faring, adapun batas-batas dari nasofaring ini antara lain batas atasnya basis kranii, batas bawahnya palatum mole, batas depannya yaitu rongga hidung dan batas belakangnya adalah vertebra 
servikal. Orofaring disebut juga mesofaring, karena terletak diantara nasofaring dan laringofaring. Batas-batas dari orofaring antara lain batas atasnya palatum mole, batas bawahnya adalah tepi atas epiglotis, batas depannya rongga mulut dan batas belakangnya vertebra servikalis. Laringofaring atau hipofaring merupakan bagian terbawah dari faring dengan batas -batasnya adalah batas atasnya epiglotis, batas bawahnya kartilago krikodea, batas depannya laring dan batas belakangnya adalah vertebra servikalis. $^{16,17}$

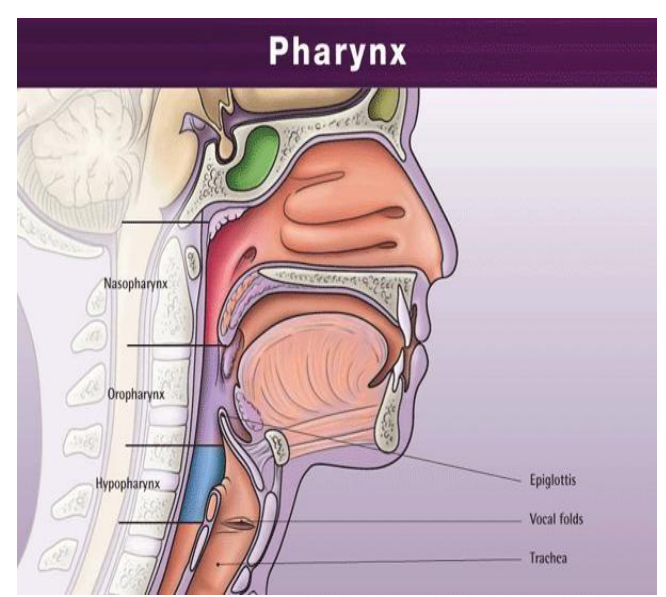

Gambar 1.1 Faring ${ }^{15}$

Laring adalah rangkaian tulang rawan yang berbentuk corong dan terletak setinggi vertebra cervicalis IV - VI, dimana pada anak-anak dan wanita letaknya relatif lebih tinggi. Laring pada umumnya selalu terbuka, hanya kadangkadang saja tertutup bila sedang menelan makanan. Laring dibentuk oleh 9 kartilago yang diikat oleh ligamen dan otot yaitu tiroid, krikoid, epiglotis, dan (sepasang) aritenoid, kornikulata dan kuneiforme. $^{17}$

Batas-batas laring berupa sebelah kranial terdapat aditus laringeus yang berhubungan dengan hipofaring, di sebelah kaudal dibentuk oleh sisi inferior kartilago krikoid dan berhubungan dengan trakea, di sebelah posterior dipisahkan dari vertebra cervicalis oleh otot-otot prevertebral, dinding dan cavum laringofaring serta disebelah anterior ditutupi oleh fascia, jaringan lemak, dan kulit. Sedangkan di sebelah lateral ditutupi oleh otot-otot sternokleidomastoideus, infrahyoid dan lobus kelenjar tiroid. $^{18}$ Kavum laring dibagi menjadi supraglotis atau vestibulum superior yaitu ruangan diantara permukaan atas pita suara palsu dan inlet laring, glotis atau pars media yaitu ruangan yang terletak antara pita suara palsu dengan pita suara sejati serta membentuk rongga yang disebut ventrikel laring morgagni dan infraglotis atau pars inferior yaitu ruangan diantara pita suara sejati dengan tepi bawah kartilago krikoidea.

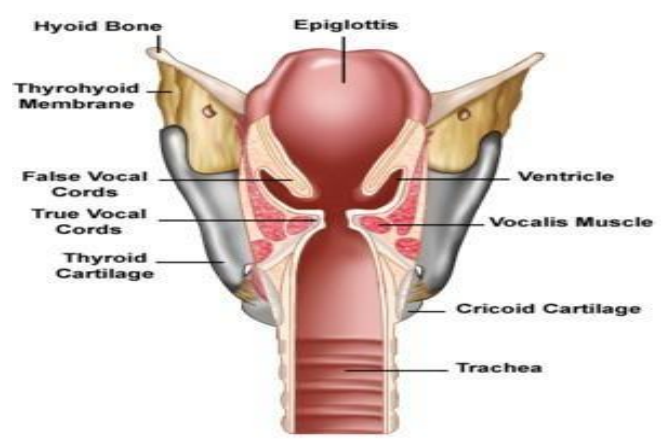

Gambar 1.2 Laring ${ }^{18}$ 
Beberapa bagian penting dari dalam laring yaitu aditus laringeus yang merupakan pintu masuk ke dalam laring, rima vestibuli merupakan celah antara pita suara palsu, rima glottis merupakan celah antara pita suara sejati, plika ventrikularis atau pita suara palsu merupakan dua lipatan tebal dari selaput lendir dengan jaringan ikat tipis di tengahnya, ventrikel laring morgagni atau sinus laringeus yaitu ruangan antara pita suara palsu dan sejati dan plika vokalis atau pita suara sejati terdapat di bagian bawah laring. Tiga per lima bagian dibentuk oleh ligamentum vokalis dan celahnya disebut intermembranous portion, dan dua per lima belakang dibentuk oleh prosesus vokalis dari kartilago aritenoidea dan disebut intercartilagenous portion. Valecula terdapat diantara permukaan anterior epiglotis dengan basis lidah, dibentuk oleh plika glossoepiglotika medial dan lateral. Plika ariepiglotika dibentuk oleh tepi atas ligamentum kuadringulare yang berjalan dari kartilago epiglotika ke kartilago aritenoidea dan kartilago kornikulata. Sinus piriformis terletak antara plika ariepiglotika dan permukaan dalam kartilago tiroidea. ${ }^{18,19}$

\section{Klasifikasi}

Angioedema dapat diklasifikasi berdasarkan durasinya yaitu akut jika berlangsung kurang dari 6 minggu dan kronis jika berlangsung lebih dari 6 minggu. Berdasarkan penyebabnya, angioedema diklasifikasikan menjadi angioedema didapat dan angioedema herediter. $^{1.6,9}$

Angioedema didapat yang terjadi akut dapat disebabkan oleh reaksi alergi yang dimediasi oleh Ig E dan sering terjadi pada orang yang memiliki riwayat atopi. Beberapa alergen yang menyebabkan reaksi alergi diantaranya adalah obat- obatan, makanan, gigitan serangga, bulu binatang, serbuk sari, spora jamur dan lain-lain. ${ }^{6}$ Angioedema didapat yang terjadi kronis dapat terjadi pada defisiensi C1-esterase inhibitor, adanya gangguan sistem kekebalan tubuh seperti pada kanker, gangguan autoimun contohnya pada sistemik lupus eritematous, adanya penyakit sistemik, penyakit infeksi serta angioedema yang terjadi akibat rangsangan fisik seperti dingin, panas, sinar matahari, gesekan dan getaran yang disebut dengan vibratory angioedema . 1,6,10 $^{1}$

Angioedema didapat yang disebabkan oleh defisiensi C1-eterase inhibitor pertama kali diperkenalkan oleh Caldwell dkk pada tahun 1972 yang kemudian dikenal sebagai angioedema didapat tipe I yang terjadi akibat dari peningkatan katabolisme dari $\mathrm{C} 1$-esterase inhibitor dan sering berhubungan dengan penyakit limfoproliferatif seperti pada myeloid leukimia kronik dan limfoma. Angioedema didapat tipe II 
diperkenalkan oleh Jackson pada tahun 1986 yaitu angioedema yang terjadi akibat adanya autoantibodi yang menyebabkan peningkatan proteolisis dari C1- esterase inhibitor menjadi molekul yang tidak aktif. ${ }^{3,9}$

Angioedema Herediter pertama kali diperkenalkan oleh William Osler pada tahun 1888. Angioedema herediter merupakan penyakit akibat kelainan autosomal dominan dimana pasien dengan angioedema herediter dapat mewarisi satu gen normal dan satu gen abnormal yang disebut dengan heterozigot. Dengan demikian, anak dari orang tua yang terkena memiliki kesempatan 50\% mewarisi gen abnormal. ${ }^{11}$

Angioedema Herediter dibedakan menjadi angioedema herediter tipe I yang disebabkan oleh defisiensi C1-esterase inhibitor dan angioedema yang terjadi karena adanya disfungsi C1-esterase inhibitor yang disebut sebagai angioedema herediter tipe II. ${ }^{9,11,14} \mathrm{C} 1$ esterase inhibitor adalah suatu glikoprotein yang terutama terbentuk di dalam hepatosit yang berfungsi sebagai regulator utama sistem kallikrein-kinin, sistem fibrinolitik dan jalur komplemen. Sebagai akibat dari aktivasi sistem kallikrein-kinin, sistem fibrinolitik dan jalur komplemen terjadi penurunan jumlah ataupun fungsi dari $\mathrm{C} 1$-esterase inhibitor dan mengakibatkan peningkatan pembentukan peptida vasoaktif seperti bradikinin. ${ }^{14}$

\section{Etiologi}

Angioedema dapat terjadi karena reaksi alergi dan non alergi yang dimediasi oleh histamin maupun bradikinin. ${ }^{9}$ Beberapa pemicu terjadinya angioedema akibat reaksi alergi diantaranya adalah obat-obatan, makanan, bulu binatang, serbuk sari, spora jamur, gigitan serangga dan lain-lain. ${ }^{6}$ Obatobatan yang sering mengakibatkan terjadinya angioedema contohnya adalah obat tekanan darah yaitu ACE inhibitor, ibuprofen, antibiotik seperti penisillin dan sulfa, aspirin, morfin, kodein serta NSAID. Beberapa makanan yang dapat menjadi pemicu terjadinya angioedema diantaranya yaitu buah-buahan, ikan, udang, daging babi, kerang, produk susu, kacang-kacangan serta cokelat. $^{2,6,10}$

Dermatografis merupakan garis yang muncul pada daerah dimana kulit tergores. Reaksi biasanya muncul setelah 2-3 menit akibat terjadinya pelepasan histamin dan menimbulkan pembengkakan di bawah kulit atau angioedema. Pembengkakan dapat membentuk garis linier. Daerah kulit yang terkena dapat gatal pada sebagian kecil pasien. Sensasi gatal biasanya menghilang setelah 30 menit. $^{1,7}$

Beberapa pemicu terjadinya angioedema nonalergi diantaranya adalah gangguan sistem kekebalan tubuh 
seperti pada kanker, gangguan autoimun pada sistemik lupus eritematous, penyakit infeksi contohnya hepatitis dan infeksi parasit usus, penyakit sistemik seperti pada gangguan tiroid serta rangsangan fisik seperti dingin, panas, sinar matahari, gesekan, goresan, tekanan serta getaran. ${ }^{1,6,10}$

Vibratory Angioedema adalah angioedema yang terjadi akibat getaran sehingga mengakibatkan terjadinya pelepasan histamin seperti yang terjadi pada pekerja- pekerja di pengasahan logam karena getaran-getaran gerinda setelah paparan selama beberapa tahun. ${ }^{6}$

Angiedema Herediter terjadi akibat defisiensi maupun disfungsi C1-esterase inhibitor. ${ }^{11}$ Angioedema didapat juga dapat terjadi akibat defisiensi C1-esterase inhibitor contohnya pada penyakit limfoproliferatif. ${ }^{3,9}$ Akibat dari adanya defisiensi maupun disfungsi C1esterase inhibitor mengakibatkan terjadinya akumulasi bradikinin sehingga timbul manifestasi klinis angioedema. ${ }^{3,7,9}$

\section{Patogenesis}

Sel Mast merupakan efektor
utama terjadinya angioedema yang
diakibatkan oleh reaksi alergi maupun
nonalergi. Sel-sel ini terletak di dalam
dermis dan menyebar di sekitar pembuluh
darah, limfosit serta saraf. Aktivasi sel
mast akibat reaksi alergi adalah melalui

antibodi immunoglobulin $\mathrm{E}$ atau Ig E di permukaan sel mast menyebabkan terjadinya degranulasi sel mast sehingga terjadinya pelepasan berbagai mediator antara lain histamin, prostaglandin D2, leukotrien $\mathrm{C} 4$, eosinofil, faktor kemotaktik neutrofil, beberapa enzim seperti triptase, cymase, carboksipeptidase A dan catepsin G, berbagai cytokin seperti interleukin 4,5,6 dan 8, tumor necrosis faktor dan proteoglikan seperti heparin dan kondroitin sulfat. Mediator-mediator tersebut terutama histamin menyebabkan terjadinya peningkatan permeabilitas kapiler dan vena. Aktivasi sel mast nonalergi dapat terjadi melalui substansi seperti neuropeptida seperti substansi P, obat-obatan, makanan dan media radiokontras. ${ }^{1,9,10}$

$A C E$ inhibitor menyebabkan angioedema dengan mencegah perubahan bradikinin menjadi metabolit yang tidak aktif dan memperpanjang efek potensialnya sehingga terjadi peningkatan akumulasi dari bradikinin. Bradikinin mengaktivasi sel mast dan terjadi vasodilatasi endothelium, kontraksi otot polos, peningkatan permeabilitas vaskuler sehingga menyebabkan terjadinya ekstravasasi plasma. $A C E$ diketahui sebagai kininase II karena salah satu peran utamanya untuk memetabolisme bradikinin menjadi metabolit tidak aktif. Ketika aktivitas 
$A C E$ dihambat oleh obat $A C E$ inhibitor, enzim lain seperti aminopeptidase memetabolisme bradikinin dan mencegah akumulasi berlebihan sehingga angioedema dapat terjadi pada orang yang memiliki aktivitas aminopeptidase yang tidak normal yang mungkin genetik akibat mutasi atau didapat yang disebabkan oleh obat yang dikonsumsi pasien. ${ }^{9,10}$

Sedangkan NSAID menyebabkan Angioedema melalui penghambatan Siklooksigenase-1 atau COX-1 akibat jumlah yang besar dari asam arakidonat ke dalam jalur lipoksigenase menyebabkan produksi yang berlebihan dari substansi vasoaktif leukotrien. Vasoaktif leukotrien bertindak sebagai reseptor di permukaan sel untuk meningkatkan permeabilitas vaskuler dan menyebabkan inflamasi. ${ }^{1,10}$

Angioedema Herediter Tipe I terjadi akibat mutasi genetik pada gen $\mathrm{C} 1$ esterase inhibitor menyebabkan rendahnya level $\mathrm{C} 1$ - esterase inhibitor. Peranan C1- esterase inhibitor diantaranya adalah inaktivasi faktor koagulasi XIIa, XIIf dan XIa, menghambat autoaktivasi komplemen $\mathrm{CI}$ dan menghambat aktivasi kallikrein. Hilangnya aktivitas penghambatan ini menyebabkan aktivasi komplemen dan peningkatan level bradikinin. Pada angioedema herediter tipe II, mutasi genetik pada gen $\mathrm{C} 1$-esterase inhibitor menghasilkan normal level C1- esterase inhibitor tetapi disfungsi C1-esterase inhibitor sehingga jalur plasma tidak dapat diatur yang menyebabkan terjadinya akumulasi bradikinin seperti yang terjadi pada angioedema tipe I. Pada angioedema didapat akibat defisiensi C1- esterase inhibitor terjadi peningkatan katabolisme C1-esterase inhibitor dan adanya autoantibodi yang menonaktifkan C1-esterase inhibitor menyebabkan akumulasi bradikinin. Angioedema herediter dan angioedema didapat juga terjadi akibat hilangnya kontrol penghambatan terhadap jalur fibrinolitik dan jalur komplemen klasik menyebabkan rendahnya atau tidak normalnya aktivitas $\mathrm{C} 1$ - esterase inhibitor sehingga terjadinya pelepasan vasoaktif peptida seperti bradikinin. Tidak seperti angioedema akibat reaksi alergi, peristiwa ini terjadi di ekstraseluler. C1-esterase inhibitor disintesis terutama oleh hepatosit dan sedikit oleh monosit. Di sirkulasi darah, C1-esterase inhibitor dikatabolisme lebih cepat daripada sintesis sehingga menyebabkan terjadinya angioedema. ${ }^{10,11}$

\section{Diagnosa Anamnesa dan Gejala Klinis}

Dari Anamnesa dapat kita peroleh adanya riwayat pajanan obat, makanan, penyakit sistemik yang diderita, penyakit infeksi, rangsangan fisik serta faktor pemicu lainnya yang dapat menyebabkan terjadinya angioedema. Disamping itu 
kita tanyakan juga adanya riwayat keluhan yang sama sebelumnya dan adanya riwayat keluarga dengan penyakit yang sama untuk mengetahui adanya angioedema herediter. Pasien biasanya datang dengan keluhan bengkak yang dapat mengenai kelopak mata, bibir, lidah, telinga, rongga mulut, leher, tangan, kaki ataupun alat kelamin. 2,6,7

Keluhan- keluhan lain juga dapat muncul sesuai dengan daerah yang terkena seperti rasa tebal, kesulitan menelan dan pada kasus yang berat dapat timbul kesulitan bernafas pada angioedema yang mengenai saluran pernafasan. Alergen yang ditelan dapat menghasilkan angioedema pada saluran pencernaan dengan gejala berupa perut kram, mual dan muntah akibat dari edema saluran pencernaan. ${ }^{11}$

Dari gejala klinis angioedema herediter dan angioedema didapat sulit dibedakan tetapi yang biasanya membedakan adalah usia timbulnya gejala. Angioedema herediter biasanya dimulai pada dekade kedua kehidupan sedangkan angioedema didapat dimulai pada dekade keempat kehidupan. ${ }^{20}$ Pada angioedema herediter didapatkan adanya riwayat keluarga dengan gejala pembengkakan mendadak yang berulang dari jaringan subkutan dan submukosa yang berlangsung selama 2- 5 hari. Serangan dapat dipicu oleh adanya trauma, operasi, prosedur gigi, stress emosi, haid, penggunaan kontrasepsi oral dan infeksi. $5,14,20$

\section{Pemeriksaan Fisik}

Pada pemeriksaan fisik dapat ditemukan adanya edema yang berbatas tegas, non-pitting, berwarna pucat atau merah muda dan tidak gatal. Angioedema yang disertai urtikaria dapat timbul rasa gatal. Edema melibatkan lapisan yang lebih dalam dari kulit yaitu dermis, jaringan subkutan dan submukosa. Seluruh tubuh harus diperiksa untuk melihat adanya edema maupun urtikaria. Selain itu diamati juga adanya perubahan suara, suara serak, stridor dan dispnea. $^{2,3,6}$ Pasien diminta untuk mengucapkan '"E", suatu cara untuk menilai adanya edema laring. Jika pasien mampu mengucapkan "E" berarti tidak ada edema laring. Pada beberapa kasus dapat juga ditemukan adanya wheezing serta hipotensi. $^{3}$ Ishoo dkk. ${ }^{21}$ mengklasifikasikan angioedema berdasarkan lokasi anatomis dan manifestasi klinisnya menjadi 4 stadium yaitu stadium 1, edema terbatas pada wajah dan bibir ; stadium 2, edema palatum mole ; stadium 3, edema lingual dan stadium 4 , edema laring.

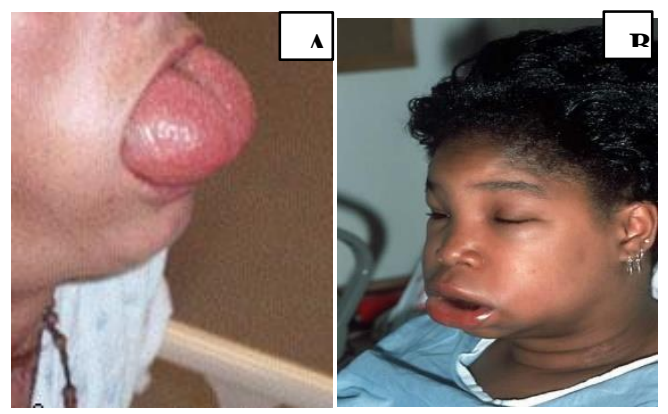


Gambar 1.3 A. Edema lingua,

B. Edema wajah dan bibir ${ }^{14}$

\section{Pemeriksaan Penunjang}

Pemeriksaan darah, urine, feses rutin dapat dilakukan untuk menilai ada tidaknya penyakit infeksi maupun penyakit sistemik. ${ }^{1,3}$ Untuk menilai adanya faktor alergi dapat dilakukan tes kulit berupa uji gores atau scratch test, uji tusuk atau prick test serta tes injeksi intradermal menggunakan serum pasien sendiri yang disebut dengan autologous serum skin test atau ASST dapat dipakai sebagai tes penyaring yang cukup sederhana untuk mengetahui adanya faktor vasoaktif seperti histamin. Tes eleminasi makanan dilakukan untuk mengetahui adanya alergi terhadap makanan tertentu dengan cara menghentikan semua makanan yang dicurigai untuk beberapa waktu, lalu mencobanya kembali satu demi satu. Tingginya serum tryptase dan histamin pada urine dapat mendeteksi angioedema yang dimediasi oleh Ig E. ${ }^{2,3,6}$

Jika diperlukan lebih lanjut dapat dilakukan pemeriksaan kadar Ig E, eosinofil serta pemeriksaan kadar C1inhibitor dan C4 komplemen. Pemeriksaan kadar serum C4 direkomendasikan sebagai tes skrining defisisensi C1-inhibitor, biasanya kadarnya kurang dari 30\% kadar nomal. Jika kadar C4 rendah maka kadar C1inhibitor dan fungsinya harus diperiksa. $^{3}$ Pada angioedema herediter tipe I terdapat rendahnya kadar dan aktivitas C1-inhibitor serta rendahnya kadar serum C4. Rendahnya kadar C1inhibitor biasanya sampai kurang dari 50\% kadar normal. Sedangkan pada angioedema herediter tipe II didapatkan kadar C1- inhibitor normal atau meningkat tetapi terjadi penurunan aktivitas atau terjadi disfungsi dari C1inhibitor dan penurunan kadar serum C4. ${ }^{11}$ Untuk membedakan angioedema herediter dan angioedema didapat akibat defisiesi C1-Inhibitor dilakukan pemeriksaan kadar C1q. Kadar C1q normal pada angioedema herediter tetapi menurun pada angioedema didapat akibat defisiesi C1-inhibitor . $3,9,11$

$$
\text { Radiografi }
$$

Abdomen,

Ultrasonografi Abdominal atau CTscan abdomen dapat dilakukan apabila terdapat kecurigaan adanya edema gastrointestinal. $^{10}$

Laringoskop Fiberoptik dapat digunakan untuk mengevaluasi secara langsung adanya edema laring., 3

\section{Diagnosis Banding}

Angioedema sering dicurigai jika terdapat edema dari kulit dan mukosa. Beberapa kondisi yang menyerupai angioedema diantaranya adalah selulitis wajah, eksema akut di wajah, sindrom vena cava superior, dermatomiositis serta pembengkakan orofaring oleh penyebab lainnya seperti tonsilitis, 
abses peritonsiler, dan benda asing di faring. $^{7}$

Pada selulitis wajah yang disebabkan oleh proses infeksi dapat dibedakan dari angioedema karena edema yang muncul sangat nyeri, berlangsung beberapa hari disertai demam dan dilanjutkan dengan terjadinya pengelupasan kulit. Eksema akut di wajah yang disebabkan oleh bahan-bahan tertentu yang sensitif dengan kulit dapat menyebabkan terjadinya dermatitis papulovesikuler, pruritus dengan gejala awal berupa eritema dan edema. Pada sindrom vena cava superior yang disebabkan oleh obstruksi yang progresif atau penyempitan dari vena cava superior yang sering disebabkan oleh invasi tumor atau efek massa dapat terjadi pembengkakan yang bertahap dari kelopak mata, bibir dan juga pembengkakan vena di wajah, leher dan dada bagian atas.

Dermatomiositis dapat muncul dengan edema keunguan pada kelopak mata yang terus menerus yang berhubungan dengan gejala sistemik dan gejala muskulokutaneus seperti kelemahan otot karena miositis dan erupsi kulit. $^{7}$

\section{Penatalaksanaan}

Dalam penatalaksanaan angioedema oleh sebab apapun yang dilakukan pertama kali adalah mengevaluasi dan mengamankan jalan nafas. Beberapa gejala yang dapat memberi tanda diperlukannya manajemen jalan nafas pada pasien dengan angioedema adalah adanya perubahan suara, suara serak, stridor serta dispnea. Tetapi perlu diingat bahwa manipulasi fisik selama evaluasi berpotensi meningkatkan edema. Intubasi endotrakeal atau trakeostomi diperlukan pada kasus yang berat. ${ }^{2,3}$

Sesuai dengan stadium angioedema yang ditetapkan oleh Ishoo dkk kemudian dilakukan penatalaksanaan angioedema yaitu stadium 1 dan stadium 2 dapat dilakukan rawat jalan, stadium 3 memerlukan rawat inap dan stadium 4 pasien memerlukan rawat inap serta dirawat di Intensive Care Unit atau ICU. ${ }^{21}$

Pasien harus diobservasi di UGD minimal 4-6 jam setelah puncak timbulnya gejala klinis angioedema. Jika terdapat gejala anafilaksis, diperlukan epinefrin dan diobservasi dalan waktu 24 jam untuk mencegah timbulnya reaksi anafilaksis berulang. ${ }^{3}$

Setelah mengevaluasi dan mengamankan jalan nafas selanjutnya dilakukan identifikasi faktor pencetus dan kemudian dieliminasi. Kebanyakan serangan angioedema akibat alergi hilang setelah 1-3 hari kontak dengan alergen dihentikan. ${ }^{3}$ Namun sebelum penyebabnya diketahui, pasien dengan 
angioedema terlebih dahulu dapat diberikan antihistamin dan kortikosteroid. $^{1-3}$

Oksigen harus diberikan pada pasien dengan angioedema didaerah kepala dan leher terutama pada pasien yang mengalami hipoksia dan kemungkinan memerlukan intubasi. Kondisi vaskuler juga harus diamankan. Infus kristaloid intravena dapat diberikan pada pasien dengan resiko gangguan keseimbangan cairan yang dapat mengakibatkan terjadinya hipotensi atau pada pasien dengan angioedema yang beresiko mengalami reaksi anafilaksis. $^{3}$

Epinefrin merupakan agonis nonselektif yang poten dari semua tipe reseptor adrenergik. Epinefrin bekerja pada reseptor alfa-1 yang menyebabkan terjadinya vasokonstriksi dan lebih sering diberikan intramuskuler di daerah anterolateral sepertiga tengah paha karena penyerapannya lebih baik dibandingkan dengan di daerah deltoid. Pemberian epinefrin subkutan memberikan hasil yang tidak menentu dan penyerapannya lebih lambat karena tergantung dari aliran darah di daerah kulit. ${ }^{3}$

Saat ini tersedia epinefrin autoinjeksi dengan dua formulasi yaitu EpiPen yang mengandung $0,3 \mathrm{ml}$ dengan pengenceran 1:1000 yaitu $0,3 \mathrm{mg}$ atau 1 $\mathrm{mg} / \mathrm{ml}$ epinefrin dan digunakan pada pasien dengan berat badan $30 \mathrm{~kg}$ atau lebih. EpiPen $\mathrm{Jr}$ mengandung $0,3 \mathrm{ml}$ dengan pengenceran 1:2000 yaitu $0,15 \mathrm{mg}$ epinefrin yang digunakan untuk pasien dengan berat badan 15 - $30 \mathrm{~kg}$. Dosis awal pada orang dewasa adalah $0,2 \mathrm{ml}-0,5 \mathrm{ml}$ atau $0,2-0,5 \mathrm{mg}$ yang pemberiannya dapat diulang tiap 5 - 15 menit sesuai kebutuhan. Dosis untuk anak-anak adalah $0,01 \mathrm{mg} / \mathrm{kgBB}$, dengan maksimal dosis $0,3 \mathrm{mg}$. Epinefrin intravena diberikan pada pasien yang memerlukan beberapa kali dosis pemberian epinefrin intramuskuler atau pada pasien dengan cardiac arrest atau gagal jantung. Dosis rekomendasi pemberian epinefrin melalui infus intravena adalah $1-4 \mathrm{mcg} / \mathrm{menit}$. Pemberian epinefrin melalui nebulizer bukan merupakan pilihan pertama pada angioedema dengan anafilaksis tetapi merupakan terapi tambahan atau dapat diberikan pada kasus angioedema yang ringan di daerah orofaring. ${ }^{2,3}$

$$
\text { Pada pasien yang sedang }
$$
mendapatkan terapi beta-bloker mungkin tidak mendapat respon yang diharapkan pada pemberian epinefrin. Pada kasus seperti ini, pemberian glukagon dapat dipertimbangkan. Glukagon dan epinefrin sama- sama memiliki efek klinis pada peningkatan level cyclic adenosine monophosphate atau cAMP. Dosis pada dewasa adalah 1 - $5 \mathrm{mg}$ diberikan secara intravena selama 5 menit. Pada anakanak, dosis yang diberikan adalah 20 $30 \mathrm{mcg} / \mathrm{kgBB}$, maksimal $1 \mathrm{mg}$ yang 
diberikan secara intravena selama 5 menit.

Antihistamin H1 generasi pertama seperti dipenhidramin digunakan untuk menangani angioedema terutama yang disebabkan oleh reaksi alergi. ${ }^{3,10}$ Pada orang dewasa diberikan dengan dosis 25 $50 \mathrm{mg}$ intravena tiap 6 jam. Dosis pediatrik adalah $1 \mathrm{mg} / \mathrm{kgBB}$ diberikan intravena dengan maksimal dosis $50 \mathrm{mg}$. Pada kasus angioedema dengan gejala alergi yang ringan, dapat diberikan intraoral. $^{3}$ Antihistamin H1 generasi kedua seperti cetirizin dapat juga diberikan tetapi masih terbatas pemberian intraoral karena belum tersedia pemberian secara parenteral. Dosis yang diberikan adalah $10 \mathrm{mg}$ tiap 24 jam. $^{3}$

Penambahan antihistamin $\mathrm{H} 2$ mungkin bermanfaat karena $15 \%$ dari reseptor histamin di kulit adalah subtipe H2. Contoh obat antihistamin H2 adalah cimetidin, ranitidin, nizatidin, dan famotidin. ${ }^{1}$ Sebuah penelitian yang dilakukan oleh Runge dkk seperti dikutip oleh Wilkerson RG pada tahun $2012^{3}$ terhadap 39 pasien menunjukkan perbaikan dari pruritus pada penambahan terapi cimetidine pada pasien yang sebelumnya sudah diberikan dipenhidramin. Pada kasus angioedema yang disebabkan oleh alergi ataupun imunologik, kombinasi antara pemberian Antihistamin H1 dan Antihistamin H2 memberikan hasil yang memuaskan. ${ }^{1}$

$$
\text { Glukokortikoid }
$$
merupakan golongan kortikosteroid yang berfungsi pada reaksi hipersensitivitas tipe I yaitu menghambat sel $\mathrm{T}$ helper yang memproduksi mediator inflamasi seperti leukotrien, prostaglandin, histamin dan bradikinin. ${ }^{3}$ Contoh dari glukokortikoid adalah metilprednisolon yang diberikan dengan dosis $125 \mathrm{mg}$ intravena dan deksametason dengan dosis 8-12 mg intravena. $^{22}$ Glukokortikoid dapat ditambahkan pada kasus-kasus yang emergensi untuk mengurangi gejala angioedema serta pada kasus angioedema yang disertai anafilaksis, akan tetapi pemberiannya tidak lebih dari 2 minggu. ${ }^{1,3}$ Penatalaksanaan angioedema herediter dibagi menjadi 3 fase yaitu penatalaksanaan episode akut, profilaksis jangka pendek dan profilaksis jangka panjang. Indikasi untuk penatalaksanaan serangan akut adalah adanya edema cervikofasial, laring, faring, serta abdominal. Profilaksis jangka pendek diindikasikan pada pasien yang akan menjalani prosedur pembedahan di daerah cervikofasial dengan resiko edema laring seperti operasi gigi, tonsilektomi operasi maksilofasial, endoskopi, bronkoskopi dan intervensi bedah yang memerlukan intubasi sedangkan profilaksis jangka panjang diberikan jika terdapat lebih dari satu kali episode edema dalam satu bulan dengan 
tujuan untuk mengurang frekuensi, tingkat keparahan dan lamanya serangan angioedema. ${ }^{22}$

Beberapa obat yang dikenal dapat digunakan untuk penatalaksanaan serangan akut adalah konsentrat C1esterase inhibitor, icatibant asetat, ecallantide, fresh frozen plasma serta asam traneksamat intravena. Untuk profilaksis jangka pendek dapat digunakan obat yang mengandung konsentrat $\mathrm{C} 1$-esterase inhibitor, fresh frozen plasma, ecallantide, icatibant asetat serta androgen seperti danazol, stanazolol dan oksalandron. Sedangkan untuk profilaksis jangka panjang digunakan androgen, antifibrinolitik seperti asam traneksamik, asam aminokaproik serta konsentrat $\mathrm{C} 1$-esterase inhibitor. ${ }^{3,22}$

Penggunaan konsentrat $\mathrm{C} 1$-esterase inhibitor untuk pengobatan serangan akut angioedema herediter pertama kali diperkenalkan pada tahun $1973{ }^{3}$ Terdapat 2 jenis obat yang mengandung konsentrat $\mathrm{C} 1$-inhibitor yang tersedia di Amerika Serikat yaitu berinert dan cinryze. ${ }^{11,23}$ Berinert merupakan produk C1-inhibitor yang diperoleh dari kumpulan plasma para pendonor yang diberikan pada suhu kamar secara intravena melalui infus. Berinert juga digunakan pada serangan akut angioedema yang disebabkan oleh ACE Inhibitor.

CSL Behring adalah sebuah pusat penelitian Angioedema Internasional mengevaluasi efektivitas berinert pada serangan akut Angioedema Herediter. Uji coba dilakukan pada 57 pasien yang diberikan berinert dengan dosis 20 unit /kgBB dan hasilnya menunjukkan perbaikan yang signifikan pada gejala dengan waktu rata - rata 0,46 jam. ${ }^{3}$ Pada tahun 2009 FDA menyetujui berinert sebagai pengobatan serangan akut angioedema herediter pada pasien dewasa dengan dosis tidak kurang dari 20 unit/kgBB. ${ }^{3,22}$

Cinryze dikembangkan oleh Farmasi Lev bekerja sama dengan Sanquin Blood Supply Foundation. Sebuah penelitian yang dilakukan terhadap 6 pasien, cinryze diberikan dengan dosis 1000 unit 2 kali seminggu untuk profilaksis serangan angioedema herediter selama kehamilan. Jumlah serangan menurun lebih dari $85 \%{ }^{3}$ Cinryze disetujui FDA pada bulan Oktober 2008 untuk digunakan sebagai profilaksis angioedema herediter pada pasien dewasa dan remaja. Dosis yang diberikan adalah 1000 unit secara intravena setiap 3 atau 4 hari. $^{3,23}$

Icatibant adalah sintetis dekapeptida dengan struktur yang mirip dengan bradikinin tetapi mengandung 5 nonproteinogenik asam amino yang berfungsi sebagai inhibitor spesifik untuk reseptor bradikinin B2. FDA menyetujui Icatibant untuk penanganan serangan 
akut angioedema herediter pada pasien 18 tahun ke atas. $^{3,22}$

Ecallantide contohnya Kalbitor adalah protein rekombinan yang terdiri dari 60 asam amino yang berfungsi sebagai inhibitor kallikrein plasma. Penghambatan kallikrein menyebabkan menurunnya pembentukan kinin termasuk bradikinin. Pada bulan Desember 2009, Ecallantide disetujui FDA untuk digunakan pada orang dewasa usia diatas 16 tahun yang mengalami serangan akut angioedema herediter dengan dosis total $30 \mathrm{mg}$ dibagi menjadi 3 kali suntikan subkutan masing-masing 10 mg. ${ }^{3,22}$

Fresh Frozen Plasma dapat digunakan sebagai terapi profilaksis pada pasien dengan angioedema herediter. Selain mengandung $\mathrm{C} 1$ inhibitor, fresh frozen plasma juga mengandung substansi seperti kininogen. Untuk serangan akut, dosis yang diberikan biasanya 2 unit yaitu 10 - $15 \mathrm{ml} / \mathrm{kgBB}$. Untuk profilaksis sebelum prosedur pembedahan pada pasien dengan riwayat angioedema herediter, dosis yang diberikan adalah 2 unit yang diberikan 1 jam sebelum dilakukan tindakan. ${ }^{3,5}$

Danazol, Stanozolol dan Oxandrolon adalah sintesis 17-alfaalkilase dari androgen yang digunakan untuk profilaksis jangka panjang dari angioedema herediter. Androgen juga digunakan untuk profilaksis pada angioedema didapat tipe I tetapi tidak efektif untuk tipe II. Androgen mempunyai efek meningkatkan sintesis hepatik dari C1 Inhibitor. Selain itu, androgen juga menyebabkan peningkatan sintesis aminopeptidase $\mathrm{P}$, enzim yang dapat menyebabkan kerusakan bradikinin $^{3}$ Obat tersebut baru memperlihatkan efek setelah beberapa hari, sehingga tidak diidikasikan untuk pengobatan serangan akut. Androgen digunakan sebagai profilaksis jangka pendek sebelum dilakukan prosedur pembedahan.

Terapi dosis tinggi diberikan mulai 1 minggu sebelum operasi. Efek samping yang mungkin muncul dari penggunaan terapi androgen adalah penambahan berat badan, ketidakteraturan menstruasi serta kelainan fungsi hati dan kontraindikasi pada kehamilan, ibu menyusui, anak-anak, pasien dengan kanker prostat, kanker payudara, serta sindrom nefrotik. ${ }^{3,24}$ Danazol adalah inhibitor gonadotropik yang kuat. Dosis awal diberikan 400-600 mg perhari diberikan sampai gejala hilang. Dosis perlahan-lahan dikurangi menjadi dosis minimal sampai 50 - 100 mg perhari. Stanozolol adalah anabolik steroid dengan sifat antikoagulan. Dosis awal $6 \mathrm{mg}$ perhari dibagi dalam 3 dosis diberikan sampai gejala hilang, kemudian dikurangi tiap 2 bulan tergantung keparahan gejala sampai dosis pemeliharaan minimal 2 
miligram 2 kali seminggu. Stanozolol telah terbukti lebih efektif daripada danazol karena frekuensi timbulnya efek samping lebih minimal. ${ }^{3}$

Oxandrolon juga telah digunakan di Amerika Serikat dan Brazil. Dosis yang digunakan adalah $0,1 \quad \mathrm{mg}$ perkilogram berat badan atau $2,5-20 \mathrm{mg}$ perhari dibagi dalam $2-4$ dosis. $^{22}$ Antifibrinolitik seperti asam traneksamat dan asam aminokaproik telah digunakan sebagai profilaksis angioedema herediter. Asam traneksamat menghambat aktivasi plasminogen yang dalam kondisi normal dihambat oleh C1-Inhibitor sehingga mengurangi perubahan plasminogen menjadi plasmin. ${ }^{3} \quad$ Antifibrinolitik tidak seefektif androgen untuk penanganan angioedema herediter tetapi merupakan obat lini pertama untuk profilaksis pada anak-anak dan wanita hamil. ${ }^{24}$ Beberapa peneliti berpendapat bahwa antifibrinolitik lebih baik dibandingkan dengan androgen dalam pengobatan angioedema didapat. ${ }^{3}$ Untuk serangan akut, asam traneksamat diberikan dengan dosis intravena atau oral $15 \mathrm{mg}$ perkilogram berat badan tiap 4 jam. Untuk profilaksis jangka pendek dosisnya 1 gram 4 kali sehari atau $75 \mathrm{mg}$ perkilogram berat badan perhari dibagi dalam 2-3 dosis dari 5 hari sebelum operasi sampai 2 hari setelah operasi. Untuk profilaksis jangka panjang dosisnya 1000 - $3000 \mathrm{mg}$ perhari dibagi menjadi 3 - 4 dosis. Efek sampingnya kram otot, mual, diare, hipotensi, pusing serta tromboemboli. Asam aminokaproik digunakan untuk profilaksis jangka panjang dengan dosis 1 gram setiap 6-8 jam, dapat meningkat menjadi 12 gram perhari dibagi menjadi 4 dosis. Efek samping utama adalah thrombosis, nekrosis otot sehingga kurang efektif dibandingkan asam traneksamat. ${ }^{3,22}$

\section{Prognosis}

Angiedema yang tidak mengganggu pernafasan tidak begitu berbahaya dan biasanya akan hilang dalam beberapa hari. Sedangkan apabila mengenai saluran pernafasan bagian atas serta berlangsung dengan cepat dapat mengancam nyawa karena terjadinya obstruksi jalan nafas. Tingkat kematian angioedema herediter cukup tinggi yaitu $30 \%-40 \%$ yang disebabkan oleh obstruksi jalan nafas bagian atas. ${ }^{11,14}$

\section{PEMBAHASAN}

Seperti dikutip oleh Papamanthos M dkk pada tahun $2010^{5}$ Angioedema pertama kali dijelaskan oleh Milton pada tahun 1876. Heinrich Quincke kemudian menyebarluaskan istilah Angioedema pada tahun 1882 dan menjelaskan Angioedema sebagai edema yang bersifat akut pada kulit. Pada tahun 1888, Wlliam Osler memperkenalkan istilah angioneurotik edema karena ada hubungan antara stres mental dengan 
kekambuhan Angioedema serta memperkenalkan adanya angioedema herediter sebagai penyakit akibat kelainan autosomal dominan. Pada tahun 1963 Donaldson dan Evan mengidentifikasi adanya defisiensi $\mathrm{C} 1$ esterase inhibitor sebagai penyebab dari Angioedema Herediter.

Angioedema terjadi karena peningkatan permeabilitas kapiler akibat mediator inflamasi sehingga timbul edema yang non-pitting, berbatas tegas, pucat dan tidak gatal yang melibatkan lapisan yang lebih dalam dari kulit yaitu dermis, jaringan subkutan, mukosa dan submukosa. Angioedema dapat timbul bersamaan dengan urtikaria sehingga bisa disertai gatal-gatal dan kemerahan. ${ }^{1-4,6}$

Angioedema di daerah THT-KL paling sering mengenai bibir, lidah, palatum, faring maupun laring. Selain itu angioedema juga dapat terjadi pada daerah mata, telinga, saluran pencernaan, kardiovaskuler, tangan, kaki serta alat kelamin. ${ }^{3,7}$

Angioedema dapat diklasifikasi berdasarkan durasinya yaitu akut jika berlangsung kurang dari 6 minggu dan kronis jika berlangsung lebih dari 6 minggu. Berdasarkan penyebabnya, angioedema diklasifikasikan menjadi angioedema didapat dan angioedema herediter. $^{1,6,9}$

Dari anamnesa dapat diperoleh informasi adanya faktor pencetus yang menyebabkan terjadinya Angioedema seperti adanya riwayat pajanan obatobatan, makanan, bulu binatang, serbuk sari, spora jamur, gigitan serangga, gangguan sistem kekebalan tubuh, penyakit infeksi, penyakit sistemik serta rangsangan fisik seperti dingin, panas, sinar matahari, gesekan, goresan, tekanan serta getaran. ${ }^{6,10}$

Akibat adanya edema di daerah yang terkena dapat timbul keluhankeluhan diantaranya yaitu rasa tebal, kesulitan menelan, serta beberapa gejala yang dapat memberi tanda diperlukannya manajemen jalan nafas seperti adanya perubahan suara, suara serak, stridor serta dispnea. $^{2,3,6,11}$ Adanya keluhan perut kram, mual dan muntah adalah akibat dari edema saluran pencernaan. ${ }^{11}$ Pada penelitian yang dilakukan oleh Khudari dkk pada tahun $2011^{25}$ dengan cara prospektif terhadap 40 pasien dengan angioedema akibat ACE inhibitor didapatkan adanya gejala disfagia sebanyak $44,7 \%$, perubahan suara $42,1 \%$, dyspnea $23,1 \%$ dan mengeluarkan air liur 7,5\%. Dari gejala klinis angioedema herediter dan angioedema didapat sulit dibedakan tetapi yang biasanya membedakan adalah usia timbulnya gejala. Angioedema herediter biasanya dimulai pada dekade kedua kehidupan sedangkan angioedema didapat dimulai pada dekade keempat 
kehidupan. Pada penelitian yang dilakukan oleh Cicardi dkk ${ }^{20}$ terhadap 43 pasien dengan angioedema didapat dan 448 pasien dengan angioedema herediter didapatkan kejadian angioedema herediter $90 \%$ terjadi pada dekade kedua dan angiedema didapat $90 \%$ terjadi pada dekade keempat. Sedangan Bork dkk seperti dikutip oleh Papamanthos M dkk pada tahun $2010^{5}$ mempelajari 123 pasien Angioedema Herediter dan mendapat kesimpulan bahwa Angioedema Herediter terbanyak muncul antara usia 11 hingga 45 tahun, sedangkan kasus termuda berusia 3 tahun. Pada angioedema herediter dari anamnesa sebagian besar ditemukan adanya riwayat keluarga namun $20 \%$ $25 \%$ dari semua kasus angioedema herediter terjadi pada pasien yang tidak memiliki riwayat keluarga. ${ }^{11}$

Dalam

penatalaksanaan angioedema, yang dilakukan pertama kali adalah mengevaluasi dan mengamankan jalan nafas. Ishoo $\mathrm{dkk}^{21}$ mengkategorikan angioedema menjadi 4 stadium yaitu stadium 1 dengan edema terbatas pada wajah dan bibir dan stadium 2 dengan edema palatum mole dapat dilakukan rawat jalan; stadium 3 dengan edema lingual memerlukan rawat inap dan stadium 4 dengan edema laring stadium 4 pasien memerlukan rawat inap serta dirawat di ICU. Pada tahun 1985-1995, Ishoo dkk melakukan penelitian terhadap
80 pasien dengan 93 kali episode angioedema didapatkan sebanyak $7 \%$ kasus memerlukan intervensi jalan nafas pada stadium 3 yaitu akibat edema lingua dan $24 \%$ kasus pada stadium 4 dengan edema laring.

Chiu dkk. pada tahun $2001^{26}$ memperkenalkan manajemen jalan nafas pada pasien dengan angioedema berdasarkan gejala klinisnya yaitu stadium 1 dengan edema di daerah wajah dan rongga mulut kecuali dasar mulut dilakukan observasi di ruangan, stadium 2 dengan edema di dasar mulut, lidah, palatum mole dan uvula dilakukan observasi di ICU dan jika memberat dilakukan intubasi dengan fiberoptik. Stadium 3 dengan edema di supraglotis dan glottis dilakukan observasi di ICU dan jika memberat dilakukan intubasi dengan fiberoptik.

Apabila terdapat gejala anafilaksis, pasien dengan angioedema diberikan epinefrin intramuskuler dan diobservasi dalan waktu 24 jam untuk mencegah timbulnya reaksi anafilaksis berulang. Pada pasien yang sedang mendapatkan terapi beta-bloker mungkin tidak mendapat respon yang diharapkan pada pemberian epinefrin. Pada kasus seperti ini, pemberian glukagon dapat dipertimbangkan. ${ }^{3}$

Setelah itu dilakukan identifikasi faktor pencetus dan kemudian dieliminasi. Sebelum 
penyebabnya diketahui, pasien dengan angioedema dapat diberikan antihistamin dan kortikosteroid. ${ }^{1-3}$ Pasien kemudian dapat dilakukan perawatan selanjutnya sesuai dengan stadium penyakitnya serta kriteria penatalaksanaan yang ditetapkan oleh Ishoo dkk. ${ }^{21}$ Pada penelitian yang dilakukan oleh Khudari $\mathrm{dkk}^{25}$ pada tahun 2011 dengan cara prospektif terhadap 40 pasien dengan angioedema akibat ACE inhibitor didapatkan pasien dengan rawat jalan $(42,5 \%)$, dirawat di ICU (50\%) dan 1 pasien dirawat di ruang rawat inap umum $(7,5 \%){ }^{14}$

Pada pasien Angioedema Herediter, antihistamin dan kortikosteroid kurang memberikan efek. $^{27}$ Penatalaksanaan angioedema herediter dibagi menjadi 3 fase yaitu penatalaksanaan episode akut, profilaksis jangka pendek dan profilaksis jangka panjang. ${ }^{22}$ Di Jerman, pengobatan episode akut angioedema herediter mengunakan konsentrat $\mathrm{C} 1-\mathrm{INH}$ yang diberikan secara intravena. Dalam keadaan darurat, fresh frozen plasma juga dapat digunakan. Di sebagian besar negara- negara Eropa, konsentrat C1-INH hanya tersedia untuk pasien yang berpartisipasi dalam program khusus, sehingga sering digunakan fresh frozen plasma. Sedangkan, untuk profilaksis jangka pendek, di Jerman biasanya menggunakan konsentrat C1-INH diberikan 1-1,5 jam sebelum operasi atau perawatan gigi. Di negara-negara di mana C1-inhibitor konsentrat tidak tersedia atau hanya tersedia dalam keadaan darurat seperti edema laring, dosis tinggi androgen diberikan selama 5-7 hari sebelum tindakan dan 2-5 hari sesudah tindakan. ${ }^{22}$ Di beberapa negara, androgen merupakan gold standar untuk profilaksis angioedema herediter. Penggunaan androgen kontraindikasi pada kehamilan, ibu menyusui, anak-anak, pasien dengan kanker prostat, kanker payudara, serta sindrom nefrotik. Antifibrinolitik adalah terapi pilihan pada kontraindikasi penggunaan androgen. ${ }^{27}$

\section{KESIMPULAN}

Angioedema di daerah THT-KL paling sering mengenai bibir, lidah, palatum, faring dan laring sehingga beresiko terjadinya obstruksi jalan nafas. Dengan demikian, diagnosis adanya angioedema sesegera mungkin sangat diperlukan. Dalam penatalaksanaan Angioedema, yang dilakukan pertama kali adalah mengevaluasi dan mengamankan jalan nafas, kemudian jika terdapat gejala anafilaksis diberikan epinefrin intramuskuler. Setelah itu dilakukan identifikasi faktor pencetus dan kemudian dieliminasi. Sebelum penyebabnya diketahui, pasien dengan angioedema dapat diberikan Antihistamin dan Kortikosteroid. Pada pasien dengan 
Angioedema Herediter, pemberian antihistamin dan kortikosteroid kurang memberikan efek. Beberapa obat yang dapat digunakan untuk penanganan angiedema herediter diantaranya konsentrat $\mathrm{C} 1$-esterase inhibitor, icatibant asetat, ecallantide, fresh frozen plasma, androgen serta antifibrinolitik.

\section{DAFTAR PUSTAKA}

1. Albert F. Finn J. Urticaria and Angioedema. Dalam : Lieberman $\mathrm{P}$, Anderson JA, penyunting. Allergic Diseases Diagnosis and Treatment.edisi ketiga. Totowa: Humana Press ; 2007.h. 199-215.

2. Koufman JA, Belafsky PC, Angioedema.Allergic, Immune and Idiopathic Disorder. In: Ballenger JJ,

Snow JB, editors. Ballenger's Otorhinolaryngology Head and Neck Surgery. $16^{\text {th }}$ ed. Chicago : BC Decker; 2003.p.1206.

3. Wilkerson RG. Angioedema In: The Emergency Department: An Evidence-Based Review. Emergency Medicine Practice 2012 November;14(11) : 1-21

4. Ali SI, Qayser Y, Roohi R. Subtle angioedema presented systemic lupus erythematosus: A case report. International Journal of Case Reports and Images (IJCRI) 2013 ; 4:521-27.

5. Papamanthos $\mathrm{M}$, Matiakis A, Tsirevelou $\mathrm{P}$, Kolokotronis $\mathrm{S}$, Skoulakis H. Hereditary Angioedema: Three Cases Report, Members of the Same Family. J Oral Maxillofac Res 2010 (Jan-Mar); 1(1):e9.

6. Arshad SH, Holgate ST, Adkinson NF, Babu KS. Allergy.An Atlas of Investigation and Management. New
York: Taylor and Francis Ltd; 2006. p. 115-123.

7. Limsuwan T, Demoly P. Acute Symptoms of Drug hypersensitivity ( Urtikaria, Angioedema, Anaphylaxis, Anaphylactic Shock ). Med Clin N2010;94: 691710.

8. Theyab AA, Lee DS, Khachemoune A. Angiotensin-Converting Enzyme Inhibitor-Induced Angioedema. Cutis. 2013;91:30-35.

9. Kloth N, Lane AS. ACE inhibitorinduced angioedema: a case report and review of current management. Critical Care and Resuscitation 2011; 13:33-37.

10. Nzeako UC. Diagnosis and management of angioedema with abdominal involvement: A gastroenterology perspective. World J Gastroenterol 2010 October 21; 16(39): 4913-21.

11. Bagal Angioedema S. Available from URL : http://www.rarediseases.org. Accessed on February 24,2013.

12. Anon JB. Hereditary angioedema: a clinical review for the otolaryngologist. Ear Nose Throat J. 2011 Jan;90(1):32-9.

13. Craig T, Pursun EA, Bork K, Bowen T, Boysen H, Farkas H et al. WAO Guideline for the Management of Hereditary Angioedema. World Allergy Organization Journal. 2012; 5:182-99.

14. Coughlin A, Siddiqui F, Quinn FB. Urticaria and Angioedema. Grand Rounds Presentation, Department of Otolaryngology The University of Texas Medical Branch (UTMB Health) April 25, 2012.

15. Boies GL, Adams GL, Higler PA. Rongga Mulut dan Faring Dalam : Effendi H, Santoso K editor. Boies Buku Ajar Penyakit THT. Alih 
bahasa: Wijaya C.edisi keenam. Jakarta : EGC 1997.p. 264-66.

16. Lowry LD, Onart S, Anatomy and Physiology of the Oral Cavity and Pharynx. In:Ballenger JJ, Snow

JB,editors.

Ballenger's

Ohinolaryngology Head and Neck

Surgery. $16^{\text {th }}$ ed. Chicago : BC Decker;2003.p.1009-1019.

17. Maves MD.Surgical Anatomy of the Head and Neck. In : Bailey BJ, Johnson JT editors. Head and Neck Surgery- Otolaryngology. $4^{\text {th }}$ Ed. Philadelphia : Lippincott Williams and Wilkins; 2006.p. 13-16.

18. Sasaki CT, Kim YH. Anatomy and Physiology of the Larynx.In: Ballenger JJ, Snow JB,editors

Ballenger's Otorhinolaryngology Head and Neck Surgery. $16^{\text {th }}$ ed. Chicago : BC Decker; 2003.p.10901100.

19. Saigusa H. Comparative Anatomy of the Larynx and Related Structures. JMAJ 2011;54(4): 241-7.

20. Cicardi M, Zanichelli A. Acquired angioedema. Allergy, Asthma and Clinical Immunology 2010, 6:14.

21. Ishoo E, Shah UK, Grillone GA, Stram JR, Fuleihan NS. Predicting airway risk in angioedema: staging system based on presentation. Otolaryngol Head Neck Surg. 1999 Sep;121(3):263

22. Caballero T, Baeza ML, Cabanas $\mathrm{R}$, Campos A,Cimbollek S,Traseira $\mathrm{CG}$,et al. Consensus Statement on the Diagnosis,Management, and Treatment of AngioedemaMediated by Bradykinin. Part II. Treatment, Follow-up, and Special Situations. J Investig Allergol Clin Immunol 2011; Vol. 21(6): 422-41.

23. Cicardi M, Bork K, CaballeroT, Craig $\mathrm{H}, \mathrm{Li} \mathrm{H}$, Longhurst $\mathrm{H}$ et al. Evidence-based recommendations for the therapeutic management of angioedema owing to hereditary $\mathrm{C} 1$ inhibitor deficiency: consensus report of an International Working Group. European Journal of Allergy and Clinical Immunology 2012 ; 67 :14757.

24. Kanani A, Schellenberg R, Warrington R. Urticaria and angioedema. Allergy, Asthma \& Clinical Immunology 2011, 7(1):59.

25. Al-Khudari S, Loochtan MJ, Peterson E, Yaremchuk KL. Management of angiotensinconverting enzyme inhibitor-induced angioedema. Laryngoscope. 2011 Nov;121(11):2327-34.

26. Chiu AG, Newkirk KA, Davidson BJ, Burningham AR, Krowiak EJ, Deeb ZE. Angiotensin-converting enzyme inhibitor-induced angioedema : a multicenter review and an algorithm for airway management. Ann Otol Rhinol Laryngol. 2001 Sep;110(9):834-40.

27. Richard G,Paula J. Hereditary Angioedema Caused By C1Esterase Inhibitor Deficiency: A Literature-Based Analysis and Clinical Commentary on Prophylaxis Treatment Strategies. World Allergy Organization Journal $2011 ; 4$ :S9-S21. 